\title{
Tribological Performance of a Ni-Based Composite Coating in Artificial Seawater
}

\author{
Bo $\mathrm{Li}^{1, *(\mathbb{D})}$, Cong $\mathrm{Li}^{1}{ }^{1} * \mathbb{D}$, Yimin Gao ${ }^{1}$, Hongjian Guo ${ }^{2}$, Yunchuan Kang ${ }^{1}$ and Siyong Zhao ${ }^{3}$ \\ 1 State Key Laboratory for Mechanical Behaviour of Materials, School of Materials Science and Engineering, \\ Xi'an Jiaotong University, Xi'an 710049, China; ymgao@mail.xjtu.edu.cn (Y.G.); \\ kangyc30@stu.xjtu.edu.cn (Y.K.) \\ 2 State Key Laboratory of Solid Lubrication, Lanzhou Institute of Chemical Physics, Chinese Academy of \\ Sciences, Lanzhou 100864, China; Chinaghj2019@hotmail.com \\ 3 Guangxi Great Wall Machineries, Hezhou 542800, China; wei9786@163.com \\ * Correspondence: libo616@mail.xjtu.edu.cn (B.L.); licong369@stu.xjtu.edu.cn (C.L.)
}

Received: 11 October 2019; Accepted: 6 November 2019; Published: 11 November 2019

check for updates

\begin{abstract}
NiCrAlY and NiCrAlY-Mo coatings were fabricated by atmospheric plasma spraying (APS). The corrosion-wear performance of the coatings was investigated in artificial seawater and the synergistic mechanism between wear and corrosion were evaluated in detail. Results showed that the diffraction peaks of $\mathrm{Ni}_{3} \mathrm{Al}$ shifted to the right and the microhardness of the coating was improved from 329.8 HV to 342.5 HV with adding the Mo element. Meanwhile, the NiCrAlY-Mo coating had a lower friction coefficient, with a wear rate of 0.26 and $3.69 \times 10^{-6} \mathrm{~mm}^{3} / \mathrm{Nm}$, compared to the NiCrAlY coating with a wear rate of 0.37 and $4.67 \times 10^{-6} \mathrm{~mm}^{3} / \mathrm{Nm}$. The NiCrAlY coating had severe corrosion and the corrosion mainly occurred in grain boundary. Adding the Mo element, the Mo element was distributed in the grain boundary and the coating had a lower corrosion rate and visibly slighter corrosion. The NiCrAlY-Mo coating had excellent corrosion-wear properties in artificial seawater.
\end{abstract}

Keywords: corrosion-wear performance; synergistic mechanism; corrosion rate; worn surface; grain boundary

\section{Introduction}

With the rapid development of the social economy and the increasing depletion of land resources, it has been difficult to meet the needs of social development, so that the rich marine sources have attracted extensive attention from researchers [1,2]. Marine equipment has played a significant role in marine exploration and development, such as offshore wind turbines, offshore platforms and ships. Nevertheless, marine equipment often directly corrodes in seawater and suffer the combined attack of corrosion and wear, which has a significant effect on the lifetime of the engineering components $[3,4]$. The synergism of corrosion and wear contain the interaction of physics, chemistry, mechanics and electrochemistry $[5,6]$. In the process of friction, the passive film on the worn surface could be destroyed by friction force and the new passive film is hard to form, which is because the galvanic corrosion takes place at the interface of the passive film and the fresh surface $[7,8]$. So the microstructure, hardness and roughness of the worn surface will be influenced by corrosion, thereby altering the wear process [3]. The corrosion-wear material loss is usually bigger than the total corrosion and wear [9,10], which could reduce the service time of marine equipment. Hence, it is very urgent to improve the corrosion-wear properties of mechanical parts in seawater.

MCrAlY ( $\mathrm{M}=\mathrm{Co}$ and/or Nickel) alloys usually act as a protective coating, having high strength, excellent corrosion resistance and wear resistance properties in corrosive environment, as well as having been employed in nuclear power, automotive and marine industries. Meanwhile, the MCrAlY 
alloys contain amounts of $\mathrm{Cr}$, which has the effect of solid solution strengthening, thus stopping the propagation of dislocations [8,11-16]. Bakhsheshi-Rad et al. researched the microstructural, mechanical properties and corrosion behavior of a plasma sprayed NiCrAlY/nano-YSZ duplex coating on an Mg-1.2Ca-3Zn alloy. The protective coating of NiCrAlY could effectively decrease the corrosion current density of the $\mathrm{Mg}$ alloy and present an excellent corrosion resistant property [11]. Mishra et al. investigated the erosion-corrosion performance of a plasma-sprayed NiCrAlY coating in a coal-fired thermal power plant. The results showed that the NiCrAlY coating played an important protective role and effectively improved the lifetime of the engineering equipment [14]. Mo has excellent wettability with metal and carbide and usually acts as the matrix strengthening phase, which could obviously improve the strength of the composite. Meanwhile, Mo is a solid lubricant when it oxidizes into $\mathrm{MoO}_{3}$ at high temperatures [17-23]. Zheng et al. fabricated the TiC-Mo composite coating by vacuum plasma spraying and investigated its microstructure and tribological property. The results showed that the Mo element had excellent wettability with TiC. Adding the Mo element, the wear resistance property of the TiC-Mo composite coating improved obviously under low and high loads [19]. Nevertheless, few researchers focus on the synergetic effect of corrosion and wear of materials. Atmospheric plasma spraying is a commonly used method, which is used to fabricate the corrosion resistance and wear resistance of coatings $[7,11]$. Meanwhile, atmospheric plasma spraying is very easy to operate and does not change the mechanical properties of the matrix [18-20].

The aim of this work is to research the corrosion-wear performance and the synergistic mechanism between corrosion and wear of plasma-sprayed NiCrAlY and NiCrAlY-Mo coatings in artificial seawater. It is expected that this work could gain some valuable information to exploit the potential of coatings in seawater circumstances.

\section{Materials and Methods}

\subsection{Materials}

The NiCrAlY and NiCrAlY-Mo coatings were fabricated by atmospheric plasma spraying (APS). The gas atomized spherical Ni22Cr10Al1.0Y and Mo powders were bought from Metco (Winterthur, Switzerland). The powders showed spherical shapes and the sizes were about 50-100 $\mu \mathrm{m}$. Two kinds of powders were mixed at a mass fraction of $10 \%$ Mo and $90 \%$ NiCrAlY using a three-dimensional mixing apparatus. The substrate material was Inconel 718 and sand-blasted by a sand-blasting machine before spraying. After being sand-blasted, the substrate was cleaned using acetone. The thickness of the coatings was about $300 \mu \mathrm{m}$. The main spraying parameters applied are shown in Table 1 . The microhardness of the coatings was measured by a MH-5-VM microhardness tester (made in Shanghai Hengyi Science and Technology Corporation, Shanghai, China) with a normal load of $300 \mathrm{~g}$ and a dwell time of $5 \mathrm{~s}$ on polished surfaces. Each specimen was measured at least ten times. The images of the powders and coatings were characterized using a field emission scanning electron microscopy (FE-SEM, Tescan Mira 3, Bron, Kohoutovice, Czech Republic). The phase composition of coatings were analyzed using a Philips X'Pert-MRD X-ray diffractometer (Eindhoven, Netherlands)with $40 \mathrm{kV}$ operating voltage and $\mathrm{Cu}-\mathrm{Ka}$ radiation over an angular range from $20-90^{\circ}$. Jade was used to analyze the XRD results.

Table 1. Spraying parameters.

\begin{tabular}{cc}
\hline Parameter & Value \\
\hline Plasma gas flow $\mathrm{Ar}, \mathrm{L} / \mathrm{min}$ & 40 \\
Secondary gas flow $\mathrm{H}_{2}, \mathrm{~L} / \mathrm{min}$ & 5 \\
Spraying angle & $90^{\circ}$ \\
Powder feed rate, g/min & 42 \\
Current, A & 500 \\
Voltage, $\mathrm{V}$ & 60 \\
Spray distance, $\mathrm{mm}$ & 110 \\
\hline
\end{tabular}




\subsection{Tribocorrosion Tests}

The tribocorrosion tests were conducted in artificial seawater, using a reciprocating ball-on-disk tribometer (UMT, Karlsruhe, Germany). The artificial seawater was fabricated according the standard of ASTM D114-98. The $\mathrm{pH}$ value of the artificial seawater was adjusted with $0.1 \mathrm{M} \mathrm{NaOH}$ to 8.2. The chemical composition of the artificial seawater is shown in Table 2. The NiCrAlY and NiCrAlY-Mo coatings acted as the working electrode. The platinum wire was used as the counter electrode and $\mathrm{Ag} / \mathrm{AgCl}$ acted as the reference electrode. During the test, the samples were held in the test cell and abraded by a stationary ball slider through a reciprocating manner under controlled load and speed conditions. The schematic diagram of the reciprocating ball-on-disc tribometer is presented in Figure 1 . Polytetrafluoroethylene (PTFE) was applied as the solution cell material, which had excellent strong acid and alkali corrosion resistance and could avoid the environmental impact. The counter ball was an $\mathrm{Al}_{2} \mathrm{O}_{3}$ ceramic ball with a diameter of $5 \mathrm{~mm}$. Ahead of the friction test, the coating was polished until the surface roughness was about $0.5 \mu \mathrm{m}$. The samples were tested at room temperature, a normal load of $5 \mathrm{~N}$, sliding speed of $0.8 \mathrm{~mm} / \mathrm{s}$, amplitude of $3.5 \mathrm{~mm}$ and duration of $60 \mathrm{~min}$. Three repeat tests were employed for every coating in artificial seawater. The wear rate was calculated through the following formula as $\mathrm{W}=\mathrm{V} / \mathrm{LF}$, where $\mathrm{W}$ was the wear rate in $\mathrm{mm}^{3} \cdot \mathrm{N}^{-1} \mathrm{~m}^{-1}, \mathrm{~V}$ was the volume loss of wear in $\mathrm{mm}^{3}, \mathrm{~L}$ was the sliding distance in $\mathrm{m}$ and $\mathrm{F}$ was the applied normal load in N. SEM and a color 3D laser scanning microscope (VK-9710, Keyence, Osaka, Japan) were used to measure the worn surfaces of the coatings.

Table 2. Chemical composition of artificial seawater.

\begin{tabular}{cc}
\hline Constituent & Concentration $(\mathrm{g} / \mathrm{L})$ \\
\hline $\mathrm{NaCl}$ & 24.530 \\
$\mathrm{Na}_{2} \mathrm{SO}_{4}$ & 4.090 \\
$\mathrm{CaCl}_{2}$ & 1.160 \\
$\mathrm{MgCl}_{2} \cdot 6 \mathrm{H}_{2} \mathrm{O}$ & 11.110 \\
$\mathrm{KCl}$ & 0.695 \\
$\mathrm{NaHCO}_{3}$ & 0.201 \\
$\mathrm{KBr}$ & 0.100 \\
$\mathrm{H}_{3} \mathrm{BO}_{3}$ & 0.027 \\
$\mathrm{SrCl}_{2} \cdot 6 \mathrm{H}_{2} \mathrm{O}$ & 0.042 \\
$\mathrm{NaF}$ & 0.003 \\
\hline
\end{tabular}

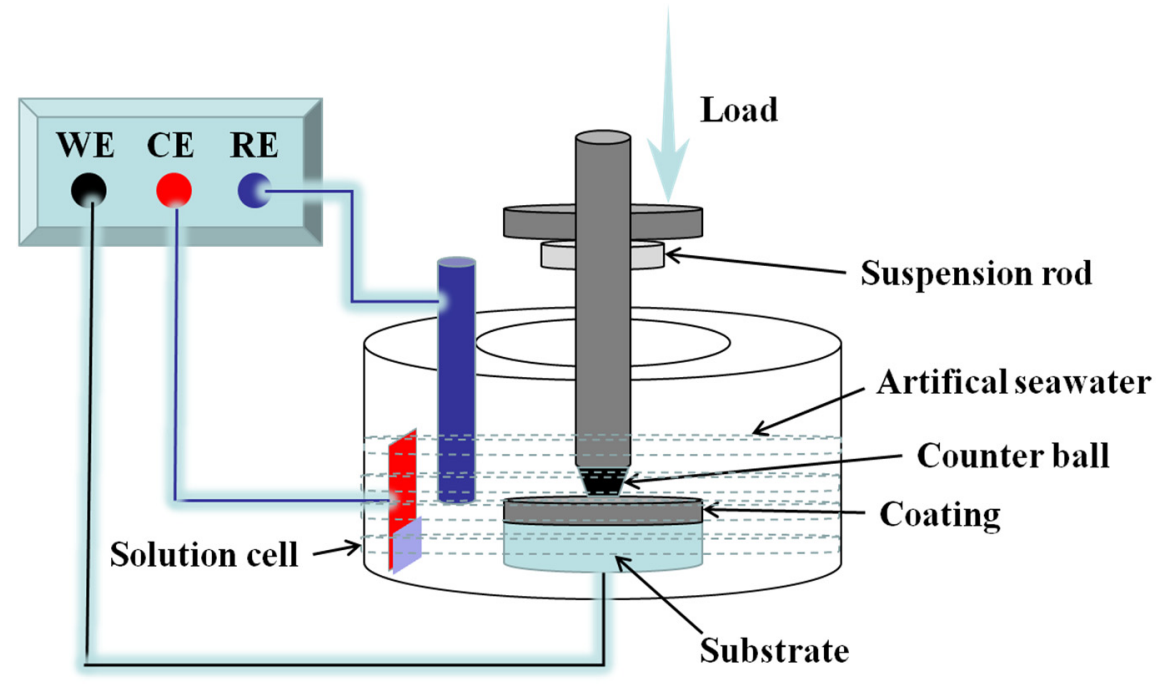

Figure 1. Schematic diagram of the reciprocating ball-on-disc tribometer. 


\section{Results and Discussion}

\subsection{Microstructure and Microhardness of Coatings}

Figure 2 gives the SEM morphologies of cross-sections of NiCrAlY and NiCrAlY-Mo coatings. The coatings contain some pores and cracks and present the typical lamellar structure. The gray part in Figure $2 \mathrm{~b}$ is Mo, which presents the strip. The two components combine with each other tightly without any evident cracks between the interface of two phases. It can be clearly seen that the NiCrAlY coating mainly contains the $\mathrm{Ni}_{3} \mathrm{Al}, \mathrm{NiAl}$ and $\mathrm{Ni}$-based solid solution from the XRD patterns of coatings (Figure 3a). The NiCrAlY-Mo coating mainly contains the $\mathrm{Ni}_{3} \mathrm{Al}$ and Mo (Figure 3a). Adding the Mo element, the diffraction peaks of $\mathrm{Ni}_{3} \mathrm{Al}$ shift to the right of $0.28^{\circ}$ (Figure $3 \mathrm{~b}$ ). It is probably due to the Mo being a solid solution in the matrix $[18,24]$.
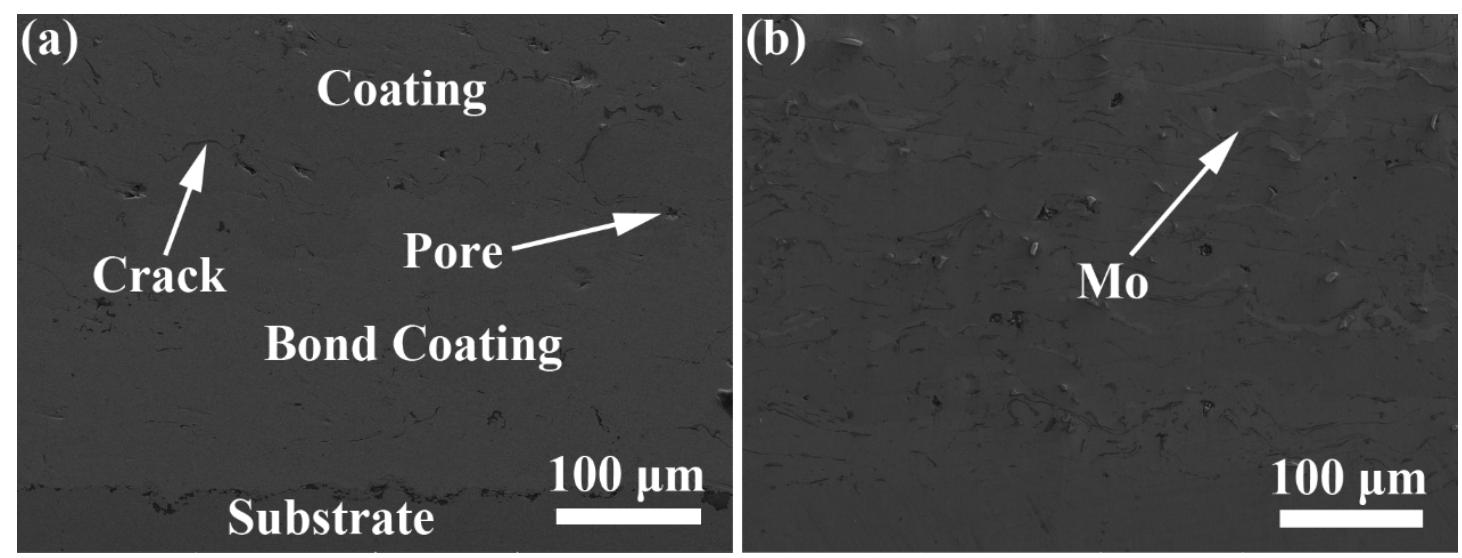

Figure 2. SEM morphologies of cross-sections of the coatings: (a) NiCrAlY and (b) NiCrAlY-Mo.
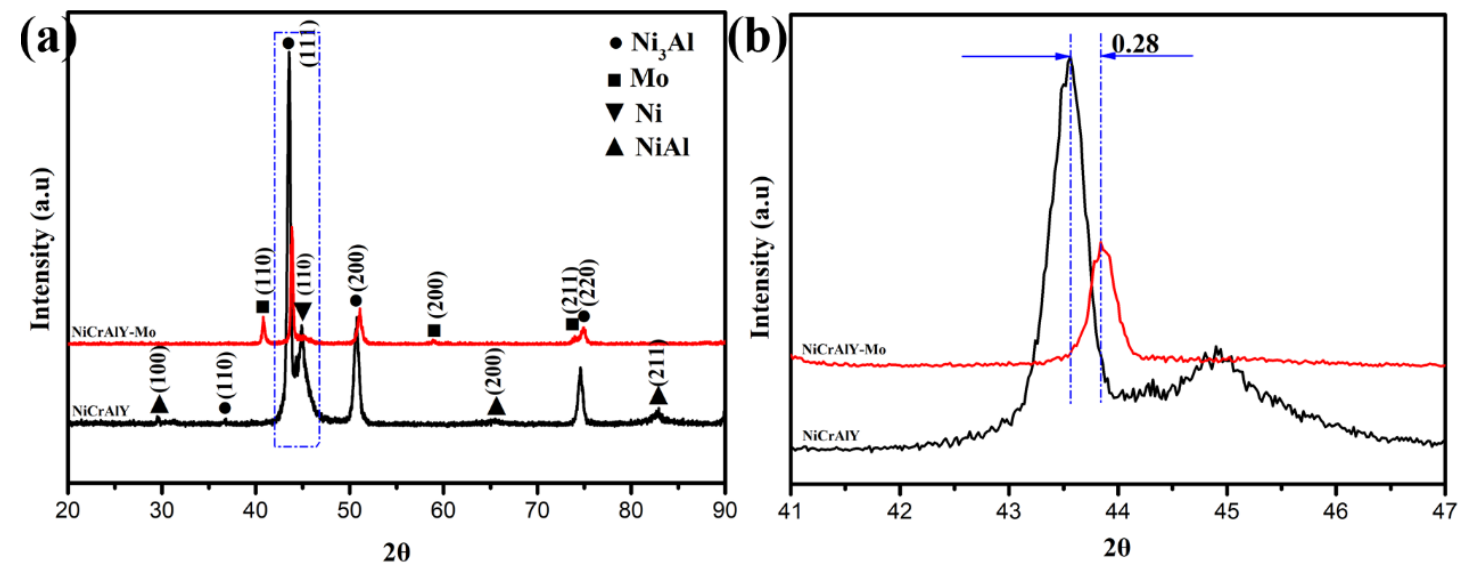

Figure 3. (a) XRD patterns of NiCrAlY and NiCrAlY-Mo coatings and (b) magnification of the region in (a).

Table 3 shows the microhardness of NiCrAlY and NiCrAlY-Mo coatings. Adding the Mo element, the microhardness of the coating is improved from 330 to $343 \mathrm{HV}$. It might be the reason for the improved microhardness of the coating as the Mo element acts as the solid solution phase in the coating.

Table 3. Microhardness of coatings.

\begin{tabular}{ccc}
\hline Coatings & NiCrAlY & NiCrAlY-Mo \\
\hline Vickers hardness (HV) & $330 \pm 16.9$ & $343 \pm 17.3$ \\
\hline
\end{tabular}




\subsection{Electrochemical Behavior of Coatings}

Figure 4 shows the evolution of the open circuit potential (OCP) before, during and after tribocorrosion of NiCrAlY and NiCrAlY-Mo coatings in artificial seawater. The coatings were immersed in artificial seawater during the first half hour and the OCP of the coatings were maintained at a steady state. When the counter ball of $\mathrm{Al}_{2} \mathrm{O}_{3}$ starts sliding on the sample surface, the OCP of the two coatings shifted to negative rapidly and maintained at a steady state. The OCP of the NiCrAlY coating was more negative than the NiCrAlY-Mo coating. Adding the Mo element, part of the Mo could be dissolved in the matrix and gives the effect of the solid solution strengthening in the coating. It is very useful to form the dense rust layer on the surface of the coating during the first half hour of immersion in artificial seawater. This dense rust layer is very hard to destroy in the process of sliding. So, the OCP of the NiCrAlY-Mo coating is more positive than the NiCrAlY coating. When the sliding stops, the OCP of the two coatings start to gradually increase, which indicate the passive film of the two coatings have been reconstructed.

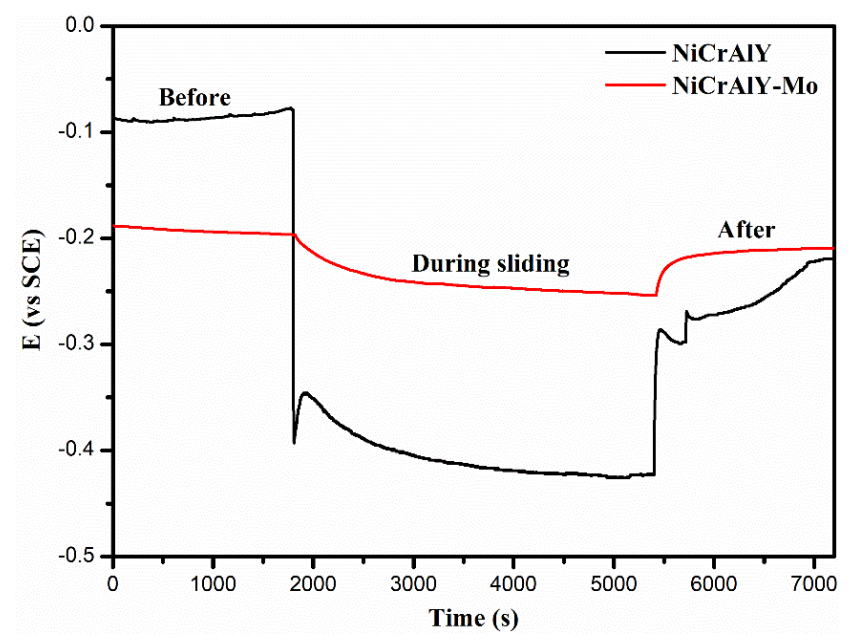

Figure 4. Evolution of OCP before, during and after tribocorrosion in artificial seawater.

Figure 5 gives the potentiodynamic polarization curves of NiCrAlY and NiCrAlY-Mo coatings in sliding condition in artificial seawater. Important parameters, such as the corrosion potential $\left(E_{c o r r}\right)$, corrosion current density $\left(i_{c o r r}\right)$, anodic and cathodic Tafel slopes $\left(\beta_{a}\right.$ and $\left.\beta_{c}\right)$ of NiCrAlY and NiCrAlY-Mo coatings, are obtained from Figure 5 through the Tafel extrapolation method and are listed in Table 4 . The polarization resistance value $\left(R_{p}\right)$ is given by the Stern-Geary equation:

$$
R_{p}=\frac{\beta_{a} \times \beta_{c}}{2.303 i_{c o r r}\left(\beta_{a}+\beta_{c}\right)}
$$

Results present that the corrosion potential $\left(E_{\text {corr }}\right)$ of the NiCrAlY-Mo coating is $-0.490 \mathrm{~V}$ (vs. SCE) and higher than the NiCrAlY coating of $-0.538 \mathrm{~V}$ (vs. SCE). It can be concluded that the NiCrAlY-Mo coating has a higher corrosion potential value, indicating that the coating is very difficult to corrode. Meanwhile, the corrosion current density $\left(i_{\text {corr }}\right)$ of the NiCrAlY-Mo coating is lower than $8.030 \times 10^{-6}$ $\mathrm{A} / \mathrm{cm}^{2}$ than that of the NiCrAlY coating of $2.243 \times 10^{-5} \mathrm{~A} / \mathrm{cm}^{2}$. In general, corrosion current density is an important standard of estimating corrosion resistance of materials, due to its rate usually being scaled with the corrosion rate of the tested material [3,25]. So, the NiCrAlY-Mo coating presents a lower corrosion rate than that of NiCrAlY coating and may be very hard to corrode. At the same time, the NiCrAlY-Mo coating has a higher $\beta_{c}$ and $R_{p}$ of $0.042 \mathrm{~V} / \mathrm{dec}$ and $8.030 \times 10^{2} \Omega$ than that of the NiCrAlY coating of $0.036 \mathrm{~V} / \mathrm{dec}$ and $3.711 \times 10^{2} \Omega$. It is further illustrated that the NiCrAlY-Mo coating under artificial seawater shows an excellent corrosion resistance. Generally speaking, the $\beta_{a}$ of the material is higher than the $\beta_{c}$ of the material [26,27]. In this test result, it can be clearly seen that the $\beta_{a}$ of the NiCrAlY-Mo coating of $0.030 \mathrm{~V} / \mathrm{dec}$ 
is lower than the $\beta_{c}$ of $0.042 \mathrm{~V} / \mathrm{dec}$. This phenomenon is related to the fact that the exchange-current density value of the anodic part is higher than that of the cathodic part. It can be understood that the entire kinetic of the NiCrAlY-Mo coating corrosion is under control with the cathodic part [16,28]. In other words, the rate of the anodic dissolution is faster than that of the cathodic reaction.

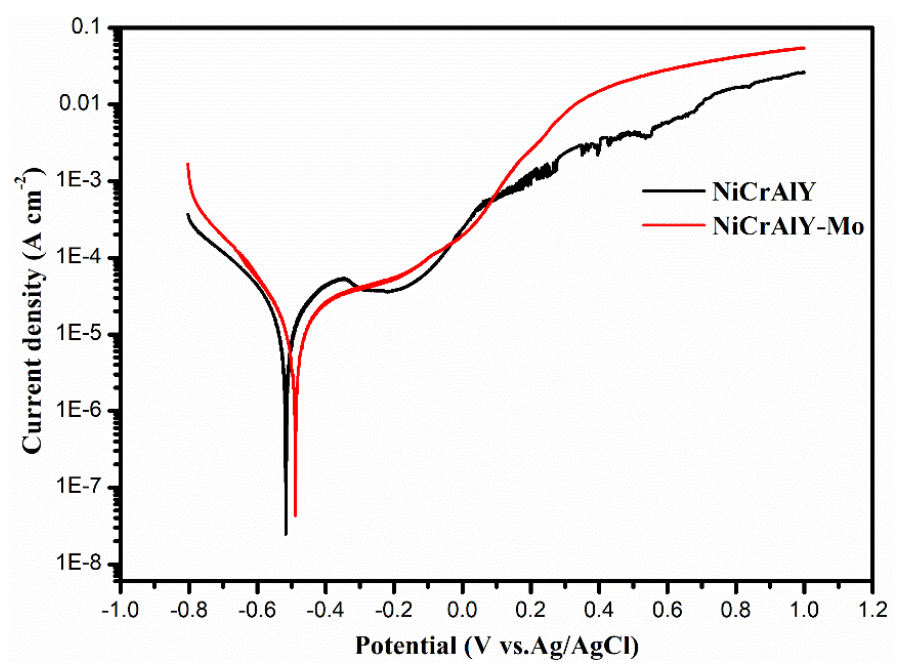

Figure 5. Potentiodynamic polarization curves of the NiCrAlY and NiCrAlY-Mo coatings' sliding condition in artificial seawater.

Table 4. Corrosion parameters of coatings from potentiodynamic polarization curves.

\begin{tabular}{cccccc}
\hline Coatings & $\boldsymbol{E}_{\text {corr }}(\mathrm{V}$, vs. SCE $)$ & $\boldsymbol{i}_{\text {corr }}\left(\mathrm{A} / \mathrm{cm}^{2}\right)$ & $\boldsymbol{\beta}_{\boldsymbol{a}}(\mathrm{V} / \mathrm{dec})$ & $-\boldsymbol{\beta}_{\boldsymbol{c}}(\mathrm{V} / \mathrm{dec})$ & $\boldsymbol{R}_{\boldsymbol{p}}(\boldsymbol{\Omega})$ \\
\hline NiCrAlY & $-0.538 \pm 0.013$ & $2.243 \times 10^{-5} \pm 1.168 \times 10^{-6}$ & 0.041 & 0.036 & $3.711 \times 10^{2}$ \\
NiCrAlY-Mo & $-0.490 \pm 0.011$ & $8.030 \times 10^{-6} \pm 0.325 \times 10^{-6}$ & 0.030 & 0.042 & $9.463 \times 10^{2}$ \\
\hline
\end{tabular}

\subsection{Friction and Wear Behavior of Coatings}

Figure 6 shows the friction curves and wear rate of NiCrAlY and NiCrAlY-Mo coatings in artificial seawater. It can be obviously seen that the friction coefficient of the NiCrAlY-Mo coating of 0.26 is lower than that of NiCrAlY coating of 0.37 . Generally speaking, the synergism between corrosion and wear in a corrosive solution make material loss large, which is usually bigger than the simple sum of wear and corrosion $[9,10]$. The wear rate of the NiCrAlY-Mo coating of $3.69 \times 10^{-6} \mathrm{~mm}^{3} / \mathrm{Nm}$ is obviously lower than that of the NiCrAlY coating of $4.67 \times 10^{-6} \mathrm{~mm}^{3} / \mathrm{Nm}$. This result is probably due to the part of the Mo that could be dissolved in the matrix. Meanwhile, the surface of the NiCrAlY-Mo coating forms a dense rust layer, which effectively decreases the corrosion rate and wear rate.
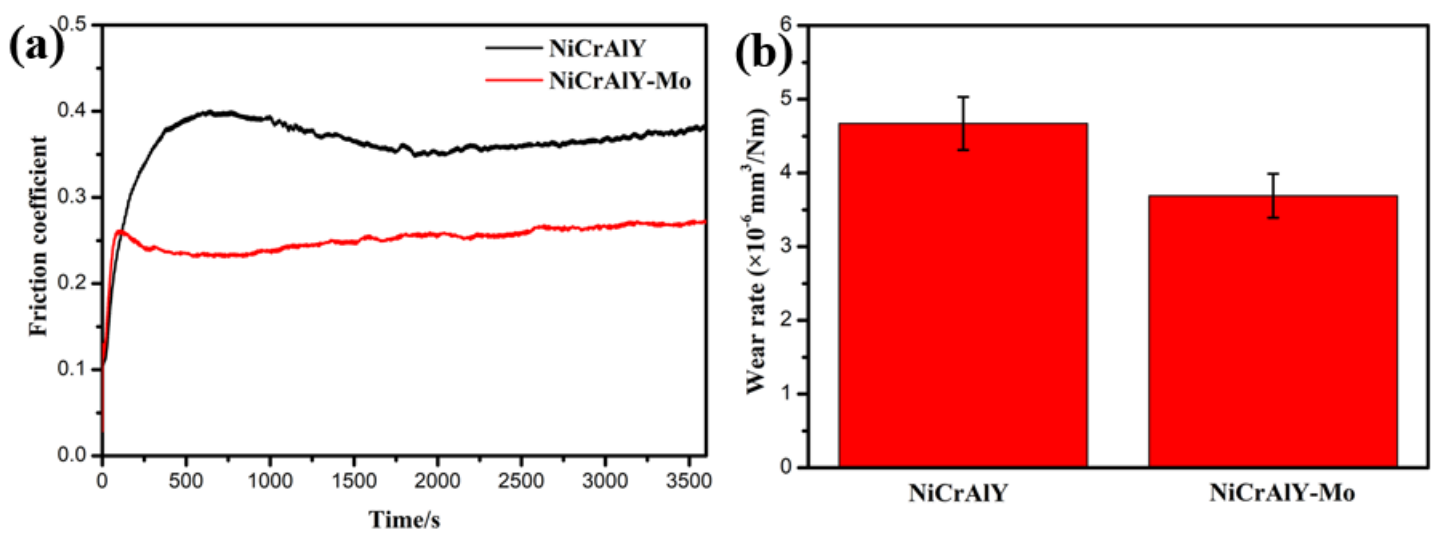

Figure 6. Friction curves (a) and wear rate (b) of NiCrAlY and NiCrAlY-Mo coatings. 
Figure 7 gives the 2D and 3D profiles of the worn surfaces of NiCrAlY and NiCrAlY-Mo coatings in artificial seawater. As can be obviously seen from figure, the worn track of the NiCrAlY-Mo coating is narrower $(223.6 \mu \mathrm{m})$ than that of the NiCrAlY coating $(261.6 \mu \mathrm{m})$. This result is in accordance with the results of the friction coefficient and wear rate (Figure 6). It is further illustrated that the NiCrAlY-Mo coating in artificial seawater presents excellent tribological properties.
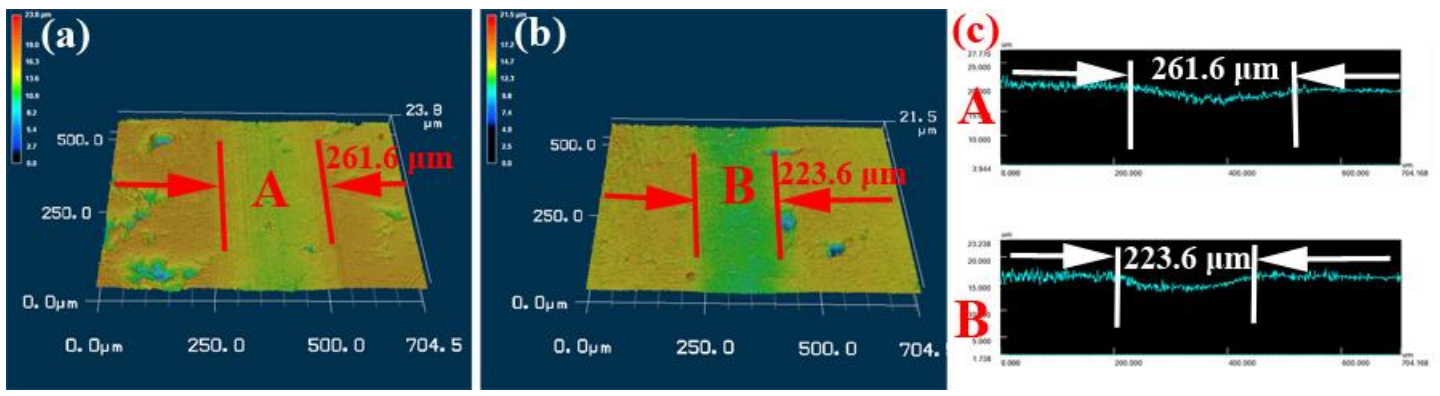

Figure 7. 2D and 3D profiles of NiCrAlY and NiCrAlY-Mo coatings: (a) NiCrAlY coating, (b) NiCrAlY-Mo coating, and (c) 2D profiles of the A and B regions.

In order to further investigate the corrosion-wear behavior of NiCrAlY and NiCrAlY-Mo coatings in artificial seawater, the SEM morphologies of the worn surfaces after the friction tests are shown in Figure 8. It can be found that the NiCrAlY coating has severe corrosion and the corrosion mainly occurs in the grain boundary (Figure 8a). Nevertheless, the NiCrAlY-Mo coating exhibits visibly slighter corrosion compared to the NiCrAlY coating (Figure 8b). As can be obviously seen from Figure 8b, the Mo element is distributed in the grain boundary, which probably improves the corrosion resistance property of the coating.
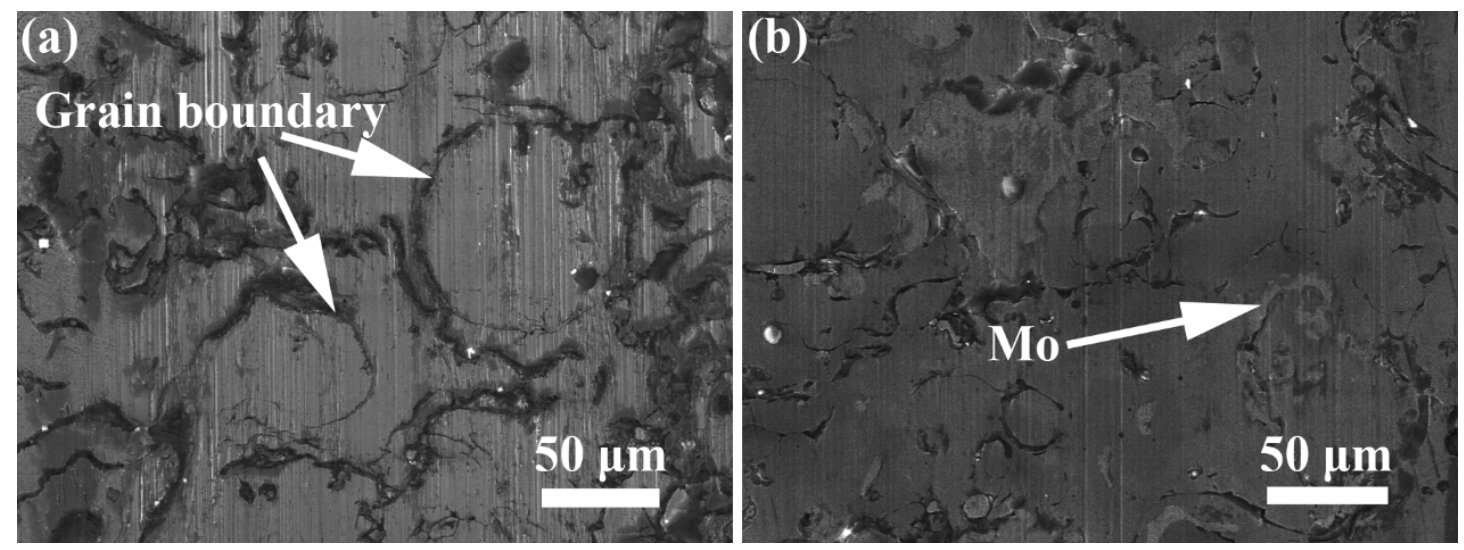

Figure 8. SEM morphologies of worn surfaces of NiCrAlY (a) and NiCrAlY-Mo (b) coatings after friction tests in artificial seawater.

\section{Conclusions}

In this work, the NiCrAlY and NiCrAlY-Mo coatings were fabricated by APS. The corrosion-wear behavior of coatings were investigated in artificial seawater and the synergistic mechanism between wear and corrosion were evaluated in detail. The main conclusions are given as follows:

(1) Adding the Mo element, the diffraction peaks of $\mathrm{Ni}_{3} \mathrm{Al}$ shift to the right and the microhardness of the coating is improved from $329.8 \mathrm{HV}$ to $342.5 \mathrm{HV}$.

(2) The NiCrAlY-Mo has a lower friction coefficient and wear rate of 0.26 and $3.69 \times 10^{-6} \mathrm{~mm}^{3} / \mathrm{Nm}^{-}$ than the NiCrAlY coating of 0.37 and $4.67 \times 10^{-6} \mathrm{~mm}^{3} / \mathrm{Nm}$. 
(3) The NiCrAlY coating has severe corrosion and the corrosion mainly occurs in the grain boundary. Adding the Mo element, the Mo element is distributed in the grain boundary and the coating has a lower corrosion rate and visibly slighter corrosion.

(4) The NiCrAlY-Mo coating had excellent corrosion-wear properties in artificial seawater.

Author Contributions: Data curation, B.L. and Y.K.; Formal analysis, S.Z.; Project administration, Y.G.; Validation, H.G.; Writing—review \& editing, C.L.

Funding: This research was funded by the National Natural Science Foundation of China (Grant No. $51805408,51665026)$, the Natural Science Foundation of Shaanxi Province (Grant No. 2019JQ-283), the China Postdoctoral Science Foundation (Grant No. 2019M653597), the Shaanxi Province Postdoctoral Science Foundation, the Fundamental Research Funds for Central Universities (Grant No. xzy012019010, xtr0118008), the Guangxi Innovation Driven Development Project (GUIKEAA18242001) and the Guangdong Province Key Area R\&D Program (2019B010942001).

Conflicts of Interest: The authors declare no conflict of interest.

\section{References}

1. Shan, L.; Wang, Y.; Zhang, Y.; Zhang, Q.; Xue, Q. Tribocorrosion behaviors of PVD CrN coated stainless steel in seawater. Wear 2016, 362, 97-104. [CrossRef]

2. Zhang, Y.; Yin, X.Y.; Yan, F.Y. Tribocorrosion behaviour of type S31254 steel in seawater: Identification of corrosion-wear components and effect of potential. Mater. Chem. Phys. 2016, 179, 273-281. [CrossRef]

3. Liu, X.; Zhao, X.; An, Y.; Hou, G.; Li, S.; Deng, W.; Zhou, H.; Chen, J. Effects of loads on corrosion-wear synergism of NiCoCrAlYTa coating in artificial seawater. Tribol. Int. 2018, 118, 421-431. [CrossRef]

4. Ma, F.; Li, J.; Zeng, Z.; Gao, Y. Structural, mechanical and tribocorrosion behaviour in artificial seawater of CrN/AlN nano-multilayer coatings on F690 steel substrates. Appl. Surf. Sci. 2018, 428, 404-414. [CrossRef]

5. Silva, R.C.C.; Nogueira, R.P.; Bastos, I.N. Tribocorrosion of UNS S32750 in chloride medium: Effect of the load level. Electrochim. Acta 2011, 56, 8839-8845. [CrossRef]

6. Zhao, Y.; Wei, F.; Zhao, X.; Yang, Q.; Guo, L.; Jiang, L. Effect of phosphorus content on mechanical properties of polymeric nickel composite materials with a diamond-structure microlattice. RSC Adv. 2018, 8, 33025-33029. [CrossRef]

7. Bonache, V.; Salvador, M.D.; García, J.C.; Sánchez, E.; Bannier, E. Influence of plasma intensity on wear and erosion resistance of conventional and nanometric WC-Co coatings deposited by APS. J. Therm. Spray Technol. 2010, 20, 549-559. [CrossRef]

8. Boztepe, E.; Alves, A.C.; Ariza, E.; Rocha, L.A.; Cansever, N.; Toptan, F. A comparative investigation of the corrosion and tribocorrosion behaviour of nitrocarburized, gas nitrided, fluidized-bed nitrided, and plasma nitrided plastic mould steel. Surf. Coat. Technol. 2018, 334, 116-123. [CrossRef]

9. Buciumeanu, M.; Bagheri, A.; Souza, J.C.M.; Silva, F.S.; Henriques, B. Tribocorrosion behavior of hot pressed CoCrMo alloys in artificial saliva. Tribol. Int. 2016, 97, 423-430. [CrossRef]

10. Mischler, S. Triboelectrochemical techniques and interpretation methods in tribocorrosion: A comparative evaluation. Tribol. Int. 2008, 41, 573-583. [CrossRef]

11. Bakhsheshi-Rad, H.R.; Hamzah, E.; Ismail, A.F.; Daroonparvar, M.; Kasiri-Asgarani, M.; Jabbarzare, S.; Medraj, M. Microstructural, mechanical properties and corrosion behavior of plasma sprayed NiCrAlY/nano-YSZ duplex coating on Mg-1.2Ca-3Zn alloy. Ceram. Int. 2015, 41, 15272-15277. [CrossRef]

12. Anwar, S.; Zhang, Y.; Khan, F. Electrochemical behaviour and analysis of Zn and Zn-Ni alloy anti-corrosive coatings deposited from citrate baths. RSC Adv. 2018, 8, 28861-28873. [CrossRef]

13. Bakhsheshi-Rad, H.R.; Hamzah, E.; Ismail, A.F.; Daroonparvar, M.; Yajid, M.A.M.; Medraj, M. Preparation and characterization of NiCrAlY/nano-YSZ/PCL composite coatings obtained by combination of atmospheric plasma spraying and dip coating on Mg-Ca alloy. J. Alloys Compd. 2016, 658, 440-452. [CrossRef]

14. Mishra, S.B.; Chandra, K.; Prakash, S. Erosion-corrosion performance of NiCrAlY coating produced by plasma spray process in a coal-fired thermal power plant. Surf. Coat. Technol. 2013, 216, 23-34. [CrossRef]

15. Peng, X.; Jiang, S.; Gong, J.; Sun, X.; Sun, C. Preparation and Hot Corrosion Behavior of a NiCrAlY + AlNiY Composite Coating. J. Mater. Sci. Technol. 2016, 32, 587-592. [CrossRef]

16. Liu, X.; An, Y.; Li, S.; Zhao, X.; Hou, G.; Zhou, H.; Chen, J. An assessment of tribological performance on NiCoCrAlYTa coating under corrosive environments. Tribol. Int. 2017, 115, 35-44. [CrossRef] 
17. Castillo-Rodríguez, M.; Nó, M.L.; Jiménez, J.A.; Ruano, O.A.; San Juan, J. High temperature internal friction in a Ti-46Al-1Mo-0.2Si intermetallic, comparison with creep behavior. Acta Mater. 2016, 103, 46-56. [CrossRef]

18. Li, B.; Gao, Y.; Jia, J.; Han, M.; Guo, H.; Wang, W. Influence of heat treatments on the microstructure as well as mechanical and tribological properties of NiCrAlY-Mo-Ag coatings. J. Alloys Compd. 2016, 686, 503-510. [CrossRef]

19. Guo, X.; Niu, Y.; Huang, L.; Ji, H.; Zheng, X. Microstructure and Tribological Property of TiC-Mo Composite Coating Prepared by Vacuum Plasma Spraying. J. Therm. Spray Technol. 2012, 21, 1083-1090. [CrossRef]

20. Ivannikov, A.Y.; Kalita, V.I.; Komlev, D.I.; Radyuk, A.A.; Bagmutov, V.P.; Zakharov, I.N.; Parshev, S.N. The effect of electromechanical treatment on structure and properties of plasma sprayed $\mathrm{Fe}-6 \mathrm{~W}-5 \mathrm{Mo}-4 \mathrm{Cr}-2 \mathrm{~V}-\mathrm{C}$ coating. Surf. Coat. Technol. 2018, 335, 327-333. [CrossRef]

21. Klimashin, F.F.; Euchner, H.; Mayrhofer, P.H. Computational and experimental studies on structure and mechanical properties of Mo-Al-N. Acta Mater. 2016, 107, 273-278. [CrossRef]

22. Li, B.; Jia, J.; Han, M.; Gao, Y.; Wang, W.; Li, C. Microstructure, mechanical and tribological properties of plasma-sprayed NiCrAlY-Mo-Ag coatings from conventional and nanostructured powders. Surf. Coat. Technol. 2017, 324, 552-559. [CrossRef]

23. Chen, Z.; Yan, H.; Liu, T.; Niu, S.; Ma, J. Improved mechanical and tribological properties of bismaleimide composites by surface-functionalized reduced graphene oxide and $\mathrm{MoS}_{2}$ coated with cyclotriphosphazene polymer. RSC Adv. 2015, 5, 97883-97890. [CrossRef]

24. Li, F.; Zhu, S.; Cheng, J.; Qiao, Z.; Yang, J. Tribological properties of Mo and $\mathrm{CaF}_{2}$ added SiC matrix composites at elevated temperatures. Tribol. Int. 2017, 111, 46-51. [CrossRef]

25. Zhang, R.; Wang, H.; Xing, X.; Yuan, Z.; Yang, S.; Han, Z.; Yuan, G. Effects of Ni addition on tribocorrosion property of TiCu alloy. Tribol. Int. 2017, 107, 39-47. [CrossRef]

26. Castillejo, F.E.; Marulanda, D.M.; Olaya, J.J.; Alfonso, J.E. Wear and corrosion resistance of niobium-chromium carbide coatings on AISI D2 produced through TRD. Surf. Coat. Technol. 2014, 254, 104-111. [CrossRef]

27. Dhandapani, V.S.; Subbiah, R.; Thangavel, E.; Arumugam, M.; Park, K.; Gasem, Z.M.; Veeraragavan, V.; Kim, D.E. Tribological properties, corrosion resistance and biocompatibility of magnetron sputtered titanium-amorphous carbon coatings. Appl. Surf. Sci. 2016, 371, 262-274. [CrossRef]

28. Kannan, A.S.; Muralidharan, S.; Sarangapani, K.B.; Balaramachandran, V.; Kapali, V. Corrosion and anodic behaviour of zinc and its ternary alloys in alkaline battery electrolytes. J. Power Sources 1995, 57, $93-98$. [CrossRef]

(C) 2019 by the authors. Licensee MDPI, Basel, Switzerland. This article is an open access article distributed under the terms and conditions of the Creative Commons Attribution (CC BY) license (http://creativecommons.org/licenses/by/4.0/). 